\title{
Arsenic oxidation by hypertolerant Bacillus sp. L-148 in artificial groundwater microcosm
}

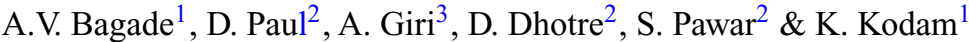 \\ ${ }^{1}$ Department of Chemistry, Savitribai Phule Pune University, Pune, India \\ ${ }^{2}$ Division of Biochemical Sciences, CSIR-National Chemical Laboratory, Pune, India \\ ${ }^{3}$ Microbial Culture Collection, National Centre for Cell Science, Pune, India
}

\begin{abstract}
A microcosm mimicking artificial groundwater harboring high (75 mM) AS(III) concentration was developed to study the rate of arsenic oxidation by Bacillus sp. L-148 under different conditions. Na. acetate and glucose as carbon sources were used along with and/or absence of Fe ions. Morphological studies revealed elongation of $75 \mathrm{mM}$ As(III) exposed bacteria along with terminal spore formation. Decrease in $\mathrm{pH}$ with time and $\mathrm{As}(\mathrm{V})$ formation was seen. Maximum $77 \%$ oxidation in presence of $\mathrm{Na}$. acetate and Fe ions on 15th day was seen. Growth studies were in analogy with As oxidation studies. Microcosm for As oxidation in presence of $0.4 \mathrm{mM}$ mixture of heavy metals $\mathrm{Cd}, \mathrm{Co}, \mathrm{Pb}, \mathrm{Li}, \mathrm{As}(\mathrm{III}), \mathrm{As}(\mathrm{V}), \mathrm{Sb}$ was studied. Effect of heavy metals on growth and As(III) oxidation was assessed. Contrastingly, here glucose served as a better carbon source but completely oxidized As(III). Thus, this microcosm study concluded that Bacillus sp. L-148 can be used for bioremediation of heavy arsenic contaminated site along with presence of other heavy metals.
\end{abstract}

\section{INTRODUCTION}

Arsenic (As) is ranked first on the" Superfund Priority List" of hazardous materials by Environmental Protection Agency and World Health Organization because of its potent carcinogenic properties. Leaching of As from the minerals into groundwater creates the contamination issues and enhances population risk of deleterious cancerous effects. In spite of the toxic nature of arsenic, microorganisms have evolved different tolerance mechanisms to reduce its harmful effects.

The bioremediation by these bacteria is usually checked by setting up microcosm at times at pilot level. As contaminated sites having $215-12500 \mathrm{mg} \mathrm{kg}^{-1}$ As in Italy (Lucia et al., 2015) and $100-2500 \mathrm{mg} \mathrm{kg}^{-1} \mathrm{As}$ in Chile soil (Oskar et al., 2016) warrants a need for a hypertolerant bacterial isolate for bioremediation. Considering this background, a microcosm of artificial groundwater with $75 \mathrm{mM}$ As(III) was set up and assessed for As oxidation, growth, $\mathrm{pH}$ variation and morphological studies. Other heavy metal contamination in groundwater is also reported, hence mixture of heavy metal in microcosm was studied for their effect on As oxidation.

\section{METHODS}

\subsection{Microcosm set up}

A 15-day experiment with $30 \mathrm{~mL}$ artificial groundwater along with $75 \mathrm{mM} \mathrm{As}(\mathrm{III})$ in presence of $2 \%$ inoculum of Bacillus sp. L-148 was set up. Two different carbon sources $(0.164 \%) \mathrm{Na}$. acetate and glucose were used separately with and without presence of $20 \mathrm{mM}$ Fe. Respective abiotic control, carbon starvation control, no Fe control, carbon starvation with Fe control were also taken. A 2nd set of microcosms to study the effect of $0.4 \mathrm{mM}$ heavy metals $(\mathrm{Cd}, \mathrm{Co}$, $\mathrm{Pb}, \mathrm{Li}, \mathrm{As}(\mathrm{III}), \mathrm{As}(\mathrm{V}), \mathrm{Sb}$ ) each on As oxidation and growth was also studied. Abiotic control was used for this set.

\subsection{Morphology and $\mathrm{pH}$ assessment}

Samples were withdrawn every 2 days and checked for $\mathrm{pH}$ change. morphological studies were done by SEM.

\subsection{Growth and rate of As oxidation}

Growth of the isolate was checked by serial diluting the sample and spread plating on $0.1 \mathrm{X}$ tryptic soya agar to get the colony forming unit $\mathrm{mL}^{-1}$. As(III) oxidation of the aliquoted samples were estimated by using molybdenum blue method (Bachate et al., 2009).

\section{RESULTS AND DISCUSSION}

\subsection{Morphological studies}

Effect of high arsenic concentration on morphology of Bacillus sp. L-148 was studied. Exposure of $75 \mathrm{mM}$ arsenic increased the length of the isolate almost by $1 \pm 0.4 \mu \mathrm{m}$. Exposing the isolate to $0.4 \mathrm{mM}$ each of $\mathrm{Cd}, \mathrm{Co}, \mathrm{Pb}, \mathrm{Li}, \mathrm{As}(\mathrm{III}), \mathrm{As}(\mathrm{V}), \mathrm{Sb}$ also exhibited increase in cell length around $0.26 \pm 0.09 \mu \mathrm{m}$. This increase in cell length is attributed to limited nutrient access which affects the cell size. A large surface to 


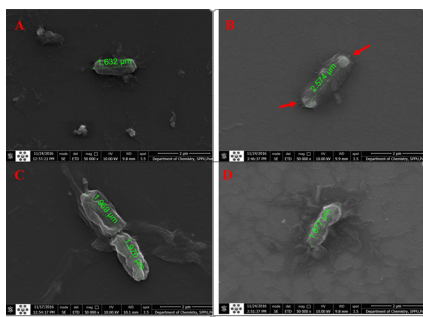

Figure 1. S.E.M of Bacillus sp. L-148: A) Control cells, B) $\mathrm{Na}$. acetate $+\mathrm{Fe}$ (endosporulation shown by red arrows); C) Na. acetate $+\mathrm{Fe}+$ multi metals; D) Glucose $+\mathrm{Fe}+$ multi metals.

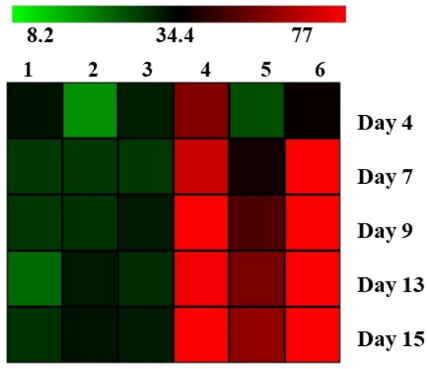

Figure 2. Heatmap showing percent As(III) oxidation 1) No carbon 2) Glucose 3) Na. acetate 4) No carbon + Fe 5) Glucose + Fe 6) Na. acetate + Fe.

volume ratio is achieved to support the internal biochemistry (Young et al., 2007). Spore formation was visible (Fig. 1B red arrows) in $75 \mathrm{mM}$ exposed cells with $\mathrm{Na}$. acetate $+\mathrm{Fe}$. Spore formation was visible on the 15th day which indicated the nutrient insufficiency, stationary phase, presence of extracellular deleterious metabolites in the artificial groundwater microcosm under study.

Influence of $\mathrm{pH}$ changes the solubility of arsenic in arsenic contaminated soil or water (Gersztyn et al., 2013). Change in $\mathrm{pH}$ of artificial groundwater microcosm was assessed throughout 15 days. In the samples containing different carbon sources and $\mathrm{Fe}$ there was gradual decrease in $\mathrm{pH}$ values as arsenic was oxidized with days. Contrastingly the metal mixture showed no decrease in $\mathrm{pH}$. As(III) oxidation decreases the $\mathrm{pH}$ but as both $\mathrm{As}(\mathrm{III})$ and $\mathrm{As}(\mathrm{V})$ were added in small concentrations along with other metals, the $\mathrm{pH}$ change was not visible in metal mixture.

\subsection{Growth and arsenic oxidation}

The growth pattern in microcosm in presence of different carbon sources, iron and their respective controls was evaluated to get a brief idea about the amount of cells involved in high arsenic oxidation and effect of the different conditions exposed on growth of the isolate. This would be important while performing on field bioremediation of arsenic contaminated sites. Growth rate was faster where $\mathrm{Na}$. acetate $+\mathrm{Fe}$ and only $\mathrm{Na}$. acetate was provided where the $\mathrm{CFU} \mathrm{mL}^{-1}$ decreased after 5 days as against 9 days seen in other conditions. We speculate this to the loss of limited nutrients provided in the microcosm (Riess et al., 2008). Sodium acetate is a metabolic byproduct of glucose catabolism hence might be preferred over glucose at times (Thomas et al., 2014).

Maximum percent As(III) oxidation was seen in sodium acetate + Fe sample (Fig. 2) which was attributed to synergistic effect of bacterial oxidation and chemical oxidation of arsenic by Fe (Hug, 2003). The decreasing order of rate of oxidation was as follows: sodium acetate $+\mathrm{Fe}>$ carbon starvation $+\mathrm{Fe}>$ glucose $+\mathrm{Fe}>$ sodium acetate $\geq$ glucose $\geq$ carbon starvation (Fig. 2). Growth and As(III) oxidation data were in correlation with each other. On the other hand, the multimetal with $0.4 \mathrm{mM}$ of As(III) and As(V) showed more growth (Fig. 1C and 1D) in glucose as carbon source. The excess stress of all heavy metals together and minimal nutrients might have rendered utilization of glucose as carbon source. As(III) $0.4 \mathrm{mM}$ in presence of heavy metals was fully oxidized on 9th day in both glucose and sodium acetate. This indicated that the isolate slowly oxidized As(III) because of the toxicity and presence of other heavy metals.

\section{CONCLUSIONS}

Bacillus sp. L-148 could oxidize $77 \%$ of $75 \mathrm{mM}$ As(III) present in artificial groundwater microcosm using Na. acetate as carbon source and in presence of $\mathrm{Fe}$. The length of the organism increased to suffice the toxicity. It could also oxidize As(III) in presence of other heavy metals. Hence Bacillus sp. L-148 holds potential to be used for bioremediation of high arsenic contaminated sites.

\section{ACKNOWLEDGEMENTS}

IIT-B,SAIF for ICP-AES analysis. University Grant Commission, India for funding.

\section{REFERENCES}

Gersztyn, L. 2013. Influence of $\mathrm{pH}$ on the solubility of arsenic in heavily contaminated soils. Environ. Prot. Nat. Resour. 3(57): 7-11.

Hug, J. 2003. Iron-catalyzed oxidation of arsenic(III) by oxygen and by hydrogen peroxide: $\mathrm{pH}$-dependent formation of oxidants in the Fenton reaction. Environ. Sci. Technol. 37(12): 2734-2742.

Riess, T. 2008. Analysis of a novel insect cell culture mediumbased growth medium for Bartonella species. Appl. Environ. Microbiol. 74(16): 5224-5227.

Thomas, V.C. 2014. A central role for carbon-overflow pathways in the modulation of bacterial cell death. PLoS Pathog. 10(6): 1-13. 